\title{
Bax-Dependent Caspase-3 Activation Is a Key Determinant in p53- Induced Apoptosis in Neurons
}

\author{
Sean P. Cregan, ${ }^{1}$ Jason G. MacLaurin, ${ }^{1}$ Constance G. Craig, ${ }^{4}$ George S. Robertson, ${ }^{3}$ Donald W. Nicholson, ${ }^{3}$ \\ David S. Park, ${ }^{1}$ and Ruth S. Slack ${ }^{1,2}$ \\ ${ }^{1}$ Neuroscience Research Institute and ${ }^{2}$ Department of Cellular and Molecular Medicine, University of Ottawa, Ottawa, \\ Ontario, K1H-8M5, Canada, ${ }^{3}$ Merck Frosst, Pointe Claire-Dorval, Quebec, H9R- 4P8, Canada, and ${ }^{4}$ Apoptogen Inc., \\ Ottawa, Ontario, $\mathrm{K} 1 \mathrm{H}-8 \mathrm{~L} 1$, Canada
}

p53 is a pivotal molecule regulating the death of neurons both after acute injury and during development. The molecular mechanisms by which p53 induces apoptosis in neuronal cells, however, are not well understood. We have shown previously that adenovirus-mediated p53 gene delivery to neurons was sufficient to induce apoptosis. In the present study we have examined the molecular mechanism by which p53 evokes neuronal cell death. Adenovirus-mediated delivery of p53 to cerebellar granule neurons resulted in caspase-3 (CPP32) activation followed by terminal deoxynucleotidyl transferase-mediated biotinylated UTP nick end labeling (TUNEL) staining and loss of viability as determined by an MTT survival assay. To determine whether Bax is essential for caspase-3 activation, p53 was expressed in Bax-deficient cells. Bax null neurons did not

Apoptosis is a biological process that plays a crucial role in nervous system development and injury. During development, cell death is essential for the regulation of neuronal cell number as well as protection against the further propagation of aberrant cells (Oppenheim, 1991; Henderson, 1996). In the mature nervous system, inappropriate cell death is implicated as an underlying defect in many types of neurodegeneration (PorteraCailliau et al., 1995; Smale et al., 1995; Thompson, 1995) as well as acute neurological insults (Linnik et al., 1993; MacManus et al., 1993; Li et al., 1995; Nitatori et al., 1995; Rink et al., 1995). Understanding the molecular events triggering apoptosis, therefore, is an important step toward the development of effective treatment strategies for such neurological diseases.

The p53 tumor suppressor gene is involved in the regulation of apoptosis in a number of different paradigms. As a tumor suppressor, the best understood function for p53 is to mediate cell cycle arrest or apoptosis after DNA damage, thereby preventing the propagation of damaged cells (for review, see Ko and Prives,

\footnotetext{
Received March 8, 1999; revised May 26, 1999; accepted July 18, 1999.

This work was supported by grants from the Heart and Stroke Foundation of Canada (O.S.C.A.R. program grant) to R.S.S. and the Medical Research Council (MRC) of Canada to R.S.S. and G.S.R. R.S.S. is an MRC Scholar, and D.S.P. is a recipient of a Glaxo Wellcome Professorship award. S.P.C. is supported by a Heart and Stroke Foundation fellowship through the O.S.C.A.R. program grant. We thank Steven Callaghan for preparing and titering recombinant adenovirus vectors and Dr. Paul Morley for assistance in these studies. We are grateful to Dr. Freda Miller for critical reading of this manuscript.

S.P.C. and J.G.M. contributed equally to this work

Correspondence should be addressed to Dr. R. S. Slack, Neuroscience Research Institute and Department of Cellular and Molecular Medicine, University of Ottawa, 451 Smyth Road, Ottawa, Ontario, K1H-8M5, Canada. E-mail address: rslack@uottawa.ca.

Copyright (C) 1999 Society for Neuroscience 0270-6474/99/197860-10\$05.00/0
}

exhibit caspase- 3 activation in response to p53 and were protected from apoptosis. To determine whether Bax-dependent caspase-3 activation was required in p53-mediated neuronal cell death, caspase-3-deficient neurons were examined. Our results indicate that caspase-3-deficient neurons exhibit a remarkable delay in apoptosis and a dramatic decrease in TUNEL-positive cells. These studies demonstrate that p53induced cell death in postmitotic neurons involves a Baxdependent caspase-3 activation, suggesting that these molecules are important determinants in neuronal cell death after injury.

Key words: apoptosis; neurodegeneration; neurons; p53; Bax; caspase-3

1996). Aberrant cell cycle regulation during development, such as the widespread CNS defect in Rb null transgenic mice, evokes a p53-mediated apoptosis (Clarke et al., 1992; Jacks et al., 1992; Lee et al., 1992). More recently, p53 has also been found to play an essential role in developmental neuronal cell death as regulated by the TrkA and p75 neurotrophin receptors (Aloyz et al., 1998). In the mature nervous system, p53 has been implicated as a key regulatory molecule after neuronal injury (for review, see Hughes et al., 1997). Brain damage induced by ischemia or kainic acid excitotoxicity has been shown to be significantly reduced in mice carrying a null mutation for the p53 gene (Crumrine et al., 1994; Morrison et al., 1996). In addition, cultured neurons derived from p53-deficient mice have been shown to be resistant to excitotoxic cell death induced by either glutamate or kainic acid (Xiang et al., 1996, 1998). Enhanced expression of p53 has been observed in injured neurons before cell death induced by focal ischemia (Chopp et al., 1992; Li et al., 1994; McGahan et al., 1998), excitotoxicity (Sakhi et al., 1996; Uberti et al., 1998), and hypoxia (Banasiak and Haddad, 1998). Finally, it has been demonstrated that p53 overexpression itself is sufficient to trigger apoptosis in primary cultures of cortical, hippocampal, and sympathetic neurons (Slack et al., 1996; Xiang et al., 1996; Jordan et al., 1997). Although these studies strongly implicate p53 as a key molecular switch leading to the death of injured neurons, the mechanism by which p53 triggers this apoptotic response is not well understood.

The signaling cascade induced by p53 is complex and likely differs depending on the type of tissue examined (for review, see Ko and Prives, 1996; Ding and Fisher, 1998). There is some evidence suggesting that Bax, a proapoptotic member of the bcl-2 
family of cell death-regulating genes, may be involved in p53induced apoptosis. The Bax gene contains p53 consensus sequences within its promoter and has been shown to be transcriptionally regulated by p53 (Miyashita et al., 1994; Miyashita and Reed, 1995). Furthermore, Bax induction has been observed during p53-mediated cell death in a number of non-neuronal cell systems (Selvakumaran et al., 1994; Z han et al., 1994; Brady et al., 1996). In neuronal cells the role of Bax in p53-induced apoptosis remains unclear; however, it appears to be important in a number of different neuronal death paradigms (Deckwerth et al., 1996; Miller et al., 1997; Johnson et al., 1998; Xiang et al., 1998).

One set of molecules that appear to be modulated by the presence of Bax are the caspases (Miller et al., 1997; Martinou et al., 1998). Caspases, a family of cysteine proteases implicated in the commitment and execution of apoptotic cell death, exist as proenzymes until cleaved in response to apoptotic stimuli (for review, see Thornberry and Lazebnik, 1998). Recent reports indicate that caspases may play a role in neuronal cell death during development (Kuida et al., 1996, 1998; Woo et al., 1998) as well as after neuronal injury (Loddick et al., 1996; Gillardon et al., 1997; Gottron et al., 1997; Hara et al., 1997; Cheng et al., 1998; Endres et al., 1998; Ni et al., 1998; Park et al., 1998).

To examine the molecular cascade by which p53 induces neuronal cell death, we have used primary cultures of cerebellar granule neurons (CGNs) derived from transgenic mice carrying null mutations for either the Bax or the caspase-3 gene (CPP32). By using adenovirus-mediated p53 gene delivery to primary neuronal cells, we demonstrate that neuronal apoptosis induced by p53 is mediated by Bax and caspase-3.

\section{MATERIALS AND METHODS}

Transgenic mice. Bax-deficient transgenic mice were generously provided by Dr. Stanley Korsmeyer (Knudson et al., 1995) and are now available from Jackson Laboratories (Bar Harbor, ME). Bax mice were originally on a mixed 129/C57BL6 strain (Knudson et al., 1995) but have since been backcrossed to C57BL6 (12-14 times) and can therefore be considered a
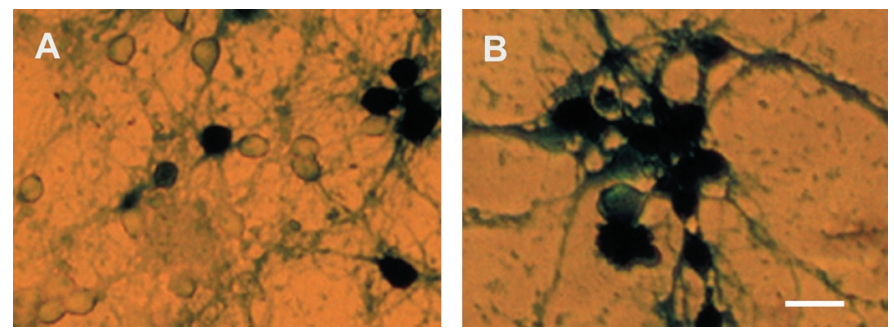

Figure 1. $\beta$-Galactosidase expression in cerebellar granule neurons. Neurons were infected at the time of plating and fixed after $72 \mathrm{hr}$ in culture. Cells infected with AdLacZ were stained with X-gal for the detection of $\beta$-galactosidase activity ( $A, 10 \mathrm{MOI}$ LacZ; $B, 50 \mathrm{MOI}$ LacZ). Scale bar, $20 \mu \mathrm{m}$.

C57BL6 genetic background. Transgenic mice carrying a caspase-3 null mutation were obtained from Dr. Don Nicholson (Merck Frosst, Canada) (E. Keramis and D. S. Park, unpublished observations). The phenotype of the caspase-3-deficient mice used in these experiments was similar to those described previously (Kuida et al., 1996; Woo et al., 1998). All caspase-3-deficient mice were maintained on a C57BL6 background to maintain genetic uniformity. Bax null mice were genotyped as described previously (Knudson et al., 1995). Caspase-3 null mice were genotyped by PCR according to the following protocol. The usual PCR reaction buffer contained $2.25 \mathrm{mM} \mathrm{MgCl}_{2}$ and $5 \%$ DMSO. The primers for the wild-type caspase-3 alleles were CTAAGTTAACCAAAGTGAGCACCGA (sense) and ATGAATCAAGGCAGCATAGTACTCC (antisense). For detection of the targeted allele, the same sense primer and the following antisense primer GTCGATCCACTAGTTCTAGAGCGGC (LZ1) were used. Conditions were set as follows: $94^{\circ} \mathrm{C}, 2$ $\min \left(1\right.$ cycle); $94^{\circ} \mathrm{C}, 30 \mathrm{sec}, 60^{\circ} \mathrm{C}, 1 \mathrm{~min}, 72^{\circ} \mathrm{C}, 1 \mathrm{~min}(30$ cycles $) ; 72^{\circ} \mathrm{C}, 5$ min (1 cycle).

Cell culture. Transgenic pups were genotyped at postnatal day 4-6, after which the appropriate animals were selected for experimentation, and neurons were cultured from brains individually. Primary cultures of cerebellar granule neurons were obtained from dissociated cerebella of postnatal day 8 or 9 mice, as described previously (Levi et al., 1984; Miller and Johnson, 1996) with some modifications. Brains were removed and placed into separate dishes containing solution A (124 mM NaCl,
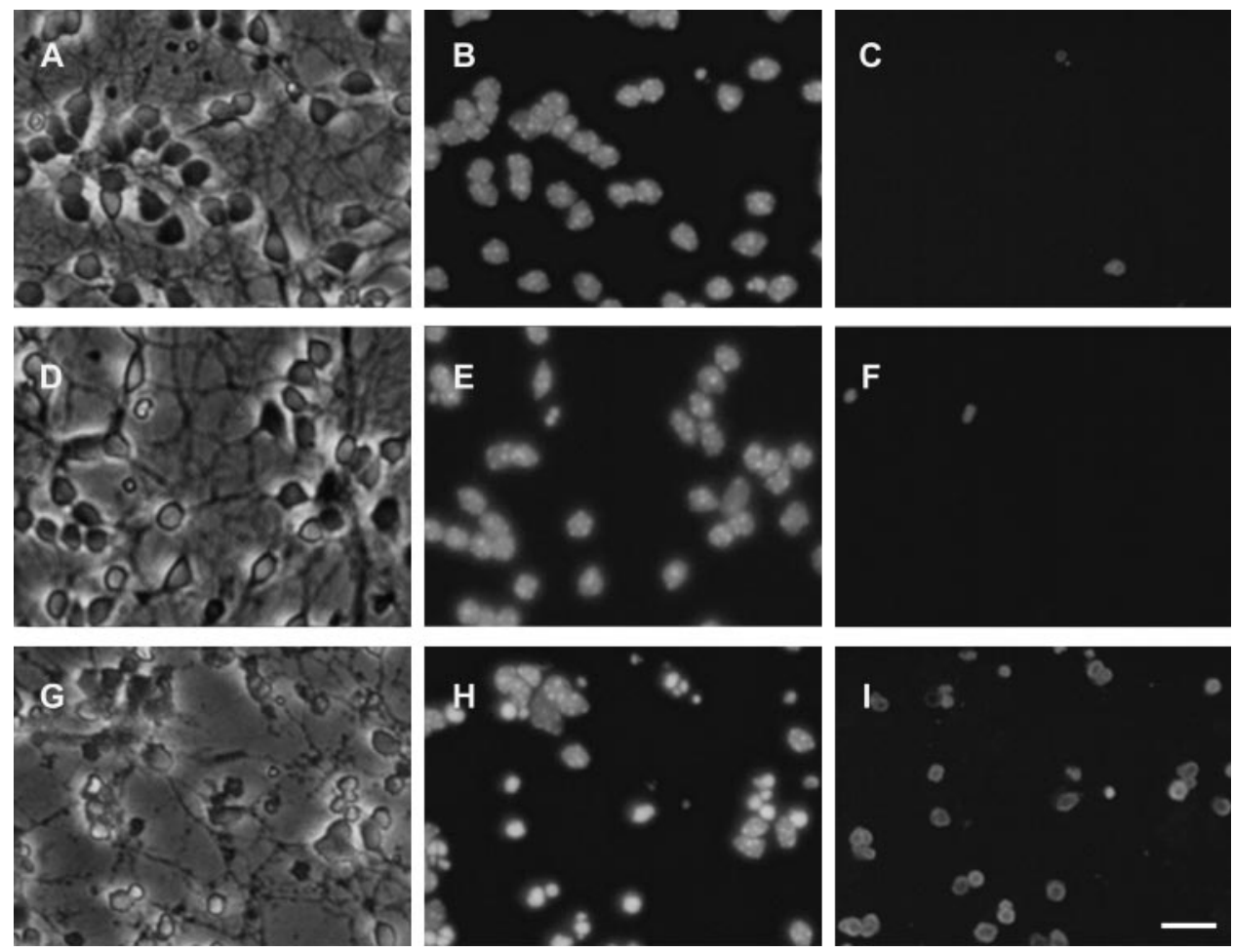

Figure 2. p53 induces apoptosis in cerebellar granule neurons. Cerebellar granule neurons were uninfected $(A-C)$ or infected at 50 MOI with AdLacZ $(D-F)$ or Adp53 $(G-I)$. After $72 \mathrm{hr}$ cells were fixed in $4 \%$ paraformaldehyde and stained for TUNEL $(C, F, I)$ and counterstained with Hoechst $(B, E, H) . A, D, G$, Corresponding phasecontrast micrographs. LacZ-infected cells retain morphology identical to uninfected controls, with no detectable increase in TUNEL staining: uninfected $(C)$ versus LacZ-infected $(F)$. In contrast, cells carrying Adp53 exhibit a significant increase in TUNEL staining $(I)$. Scale bar, $20 \mu \mathrm{m}$. 

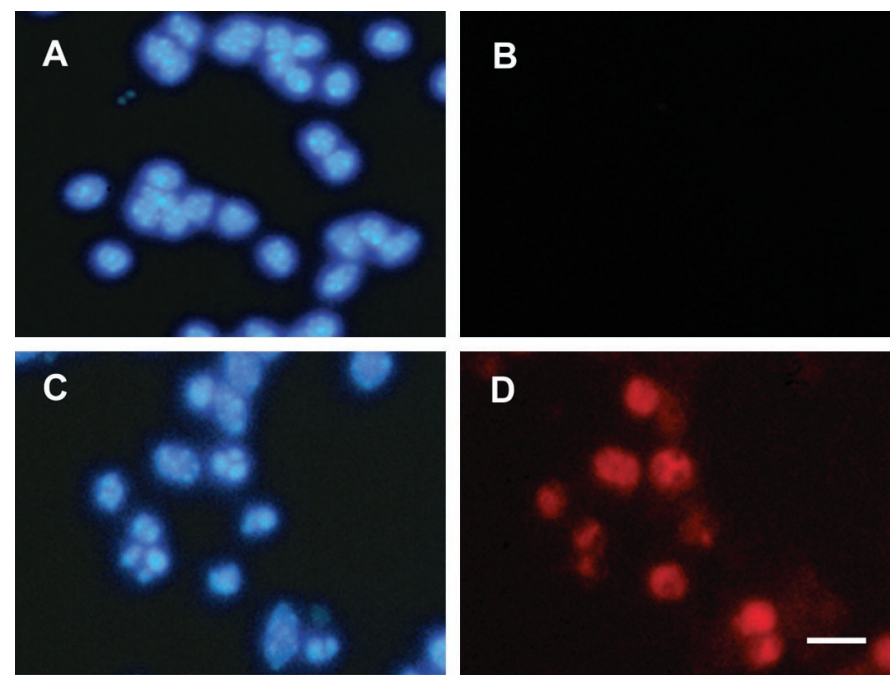

Figure 3. p53 expression in cerebellar granule neurons. Neurons infected at $50 \mathrm{MOI}$ with either $\operatorname{AdLacZ}(A, B)$, as controls, or Adp53 $(C, D)$ were fixed in $4 \%$ paraformaldehyde after $72 \mathrm{hr}$ and stained with an antibody directed against human $\mathrm{p} 53(B, D)$ and counterstained with Hoechst $(A$, C). Scale bar, $20 \mu \mathrm{m}$.

$5.37 \mathrm{~mm} \mathrm{KCl}, 1 \mathrm{~mm} \mathrm{NaH} \mathrm{PO}_{4}, 1.2 \mathrm{~mm} \mathrm{MgSO}_{4}, 14.5 \mathrm{~mm}$ D-(+)-glucose, $25 \mathrm{~mm}$ HEPES, $3 \mathrm{mg} / \mathrm{ml}$ BSA, pH 7.4) in which the cerebella were dissected, meninges removed, and tissue sliced into small pieces. Tissue was briefly centrifuged and transferred to solution A containing 0.25 $\mathrm{mg} / \mathrm{ml}$ trypsin, then incubated at $37^{\circ} \mathrm{C}$ for $18 \mathrm{~min}$. After the addition of $0.082 \mathrm{mg} / \mathrm{ml}$ trypsin inhibitor (Boehringer Mannheim, Indianapolis, IN) and $0.25 \mathrm{mg} / \mathrm{ml}$ DNase I (Boehringer Mannheim), tissue was incubated at $25^{\circ} \mathrm{C}$ for $2 \mathrm{~min}$. After a brief centrifugation, the resulting pellet was gently triturated in solution A yielding suspension that was further incubated for $10 \mathrm{~min}$ at $25^{\circ} \mathrm{C}$ in solution A containing $2.7 \mathrm{~mm} \mathrm{MgSO}_{4}$ and $0.03 \mathrm{mM} \mathrm{CaCl}_{2}$. After a final centrifugation the pellet was resuspended in EMEM media (Sigma, St. Louis, MO) containing 10\% dialyzed FBS (Sigma), $25 \mathrm{~mm} \mathrm{KCl,} 2 \mathrm{~mm}$ glutamine (Life Technologies BRL, Gaithersburg, MD), $25 \mathrm{~mm}$ glucose, and $0.1 \mathrm{mg} / \mathrm{ml}$ gentamycin (Sigma) and filtered through a cell strainer (size $70 \mu \mathrm{m}$; Falcon). Cells were plated at a density of $1.5 \times 10^{6}$ cells per milliliter of medium on either Nunc four-well or $35 \times 10 \mathrm{~mm}$ dishes (Life Technologies BRL) coated with poly-D-lysine (Sigma). Cytosine- $\beta$-arabinoside (10 $\mu \mathrm{M}$; Sigma) was added $24 \mathrm{hr}$ after plating.

Recombinant adenovirus infection. Recombinant adenovirus vectors carrying the human p53 or LacZ expression cassettes were kindly provided by Dr. Frank Graham (McMaster University, Hamilton, Ontario) (Bacchetti and Graham, 1993). In preliminary studies it was determined that treatment of cells with recombinant adenovirus vectors at a multiplicity of infection (MOI) of $50 \mathrm{pfu} /$ cell resulted in a high degree of transgene expression (as shown by X-gal staining) with minimal toxicity; thus all further experiments were performed at this titer. Recombinant adenovirus vectors were added to cell suspensions immediately before plating. Cell survival assay. Two different assays were used to measure cell survival: TUNEL labeling and a quantitative MTT assay. The colorimetric MTT survival assay (Cell Titer Kit, Promega, Madison, WI) that measures the mitochondrial conversion of the tetrazolium salt to a blue formizan salt was used as described previously (Slack et al., 1996). To assay apoptosis, TUNEL labeling was used to visualize cells with fragmented DNA. Cells were harvested 72 and $96 \mathrm{hr}$ after p53 or LacZ gene delivery and fixed in $4 \%$ paraformaldehyde for $10 \mathrm{~min}$ followed by acetone/methanol (1:1) for $1 \mathrm{~min}$. Cells were then washed in three changes of PBS and incubated for $1 \mathrm{hr}$ at $37^{\circ} \mathrm{C}$ with $75 \mu \mathrm{l}$ of a mixture (Boehringer Mannheim) consisting of $0.5 \mu \mathrm{l}$ terminal transferase, $0.95 \mu \mathrm{l}$ biotin-16-dUTP, $6.0 \mu \mathrm{l} \mathrm{CoCl}_{2}, 15.0 \mu \mathrm{l} 5 \times$ TdT buffer, and $52.55 \mu \mathrm{l}$ distilled water. Cells were then washed three times in PBS and incubated with a streptavidin Cy2 secondary antibody (Jackson Immunoresearch Laboratories, West Grove, PA). Cells were counterstained with Hoechst 33258 , and the fraction of TUNEL-positive cells was determined. A minimum of 500 cells was scored for each treatment, and the data represent the mean of three independent experiments.
48 HOURS

72 HOURS

Con. AdLacZ Adp53

Con. AdLacZ Adp53

p53
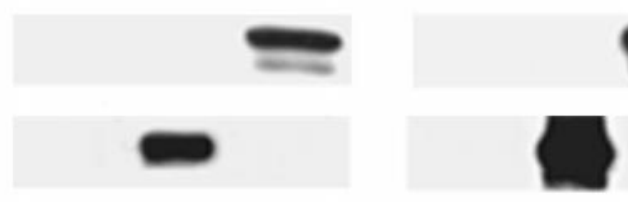

LacZ

Actin

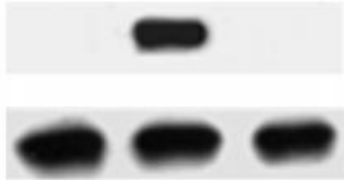

$\longrightarrow$

Figure 4. p53 and LacZ protein levels in cerebellar granule neurons. Neurons were either uninfected or infected at $50 \mathrm{MOI}$ at the time of plating with either AdLacZ or Adp53. After 48 and $72 \mathrm{hr}$, protein was extracted and Western blot analysis was performed to visualize transgene expression.

Caspase protease activity assays. Cells were harvested and extracted for $15 \mathrm{~min}$ on ice in a lysis buffer consisting of $1 \mathrm{~mm} \mathrm{KCl,} 10 \mathrm{~mm}$ HEPES, $\mathrm{pH} 7.4,1.5 \mathrm{~mm} \mathrm{MgCl}_{2}, 1 \mathrm{~mm}$ DTT, $1 \mathrm{~mm}$ PMSF, $5 \mu \mathrm{g} / \mathrm{ml}$ leupeptin, 2 $\mu \mathrm{g} / \mathrm{ml}$ aprotinin, and $10 \%$ glycerol. Lysates were centrifuged for 10 $\mathrm{min}$ at $15,000 \mathrm{rpm}$, and supernatants were removed and assayed for protein content. To measure caspase activity, aliquots of cell extracts containing $10 \mu \mathrm{g}$ of protein were added to a reaction buffer $(25 \mathrm{~mm}$ HEPES at pH 7.4, 10 mM DTT, 10\% sucrose, 0.1\% CHAPS) (Stefanis et al., 1996) containing $15 \mu \mathrm{M} \mathrm{N}$-acetyl-Asp-Glu-Val-Asp-(7-amino-4 trifluoromethyl-coumarin (DEVD-AFC), $40 \mu \mathrm{M} N$-acetyl-Asp-GluVal-Asp-p-nitroanilide (DEVD-pNA) for caspase-3-like protease activity, or $40 \mu \mathrm{M} N$-acetyl-Tyr-Val-Ala-Asp- $p$-nitroanilide (YVAD-pNA) (Biomol Research Laboratories, Plymouth Meeting, PA) for caspase-1like protease activity and incubated at $37^{\circ} \mathrm{C}$ for $2 \mathrm{hr}$. DEVD-AFC cleavage was measured using an SLM 8000 fluorometer (excitation 400 $\mathrm{nm}$ and emission $505 \mathrm{~nm}$ ), and DEVD-pNA and YVAD-pNA cleavage were measured at $405 \mathrm{~nm}$ in a spectrophotometer.

Western blot analysis. Cells were extracted as above, and aliquots containing $30 \mu \mathrm{g}$ of protein were separated on a $10 \%$ acrylamide gel and transferred to a nitrocellulose membrane. After they were blocked for 2 hr with 5\% skim milk, membranes were incubated for $1 \mathrm{hr}$ with either a rabbit polyclonal antibody directed against p53 (CM-1; Novacastra Laboratories, Newcastle upon Tyne, UK), a mouse monoclonal antibody $(\mathrm{mAb})$ specific for caspase-3 (Merck Frosst Research, Pointe ClaireDorval, PQ), LacZ (Cappell, Durham, NC), or a goat polyclonal antibody directed against actin (Santa Cruz Biotechnologies, Santa Cruz, CA). After three washes with TPBS (25 mM Na $2 \mathrm{HPO}_{4}, 5 \mathrm{~mm} \mathrm{NaH}_{2} \mathrm{PO}_{4}$, $0.9 \% \mathrm{NaCl}, 0.1 \%$ Tween-20), membranes were incubated for $1 \mathrm{hr}$ at $25^{\circ} \mathrm{C}$ with the appropriate secondary antibody, washed five times for $5 \mathrm{~min}$ each in TPBS, and then developed by an enhanced chemiluminescence system according to the manufacturer's instructions (Amersham, Arlington Heights, IL).

Immunofluorescence. For immunofluorescence detection of human p53 delivered by adenovirus vectors, neuronal cultures were fixed for $10 \mathrm{~min}$ in $4 \%$ paraformaldehyde followed by acetone/methanol (1:1) for $1 \mathrm{~min}$. Cells were then washed three times with PBS and incubated at $25^{\circ} \mathrm{C}$ for $1 \mathrm{hr}$ with a mouse $\mathrm{mAb}$ specific for an amino-terminal epitope of human p53 (DO-1; Santa Cruz). After three washes in PBS, cells were incubated for $1 \mathrm{hr}$ at $25^{\circ} \mathrm{C}$ with a $\mathrm{Cy} 3$-conjugated goat anti-mouse secondary antibody (Jackson Immunoresearch Laboratories). Cells were then washed three times in PBS, counterstained with Hoechst 33258, and visualized by fluorescent microscopy.

\section{RESULTS}

\section{p53 induces apoptosis in cultured cerebellar granule neurons}

Recombinant adenovirus-mediated delivery of p53 has previously been shown to induce cell death in various post-mitotic neurons (Slack et al., 1996; Xiang et al., 1996; Jordan et al., 1997). To determine whether p53 overexpression could induce cell death in cultured cerebellar granule neurons, CGNs were infected at 50 MOI with recombinant adenoviruses carrying an expression cassette for either the human p53 gene (Adp53) or the 
A.

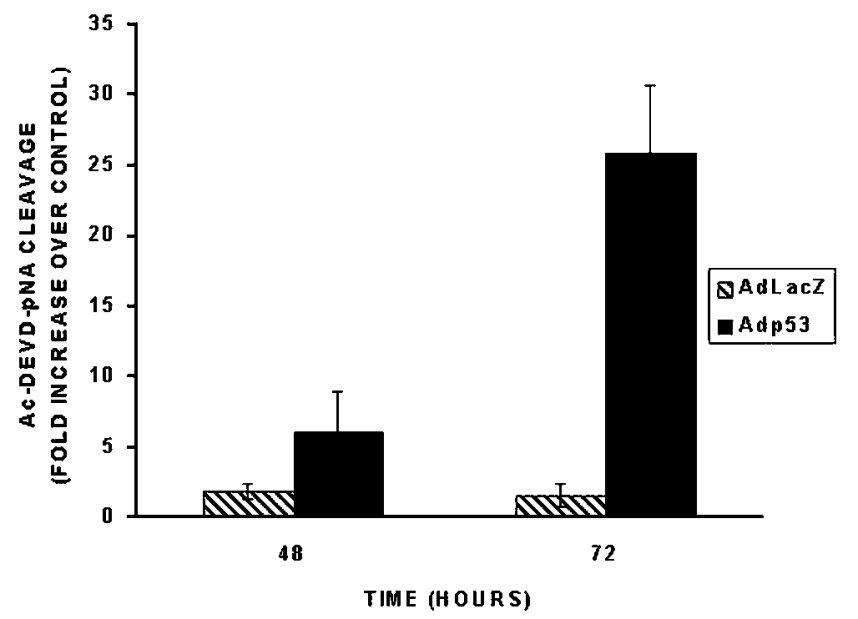

в.

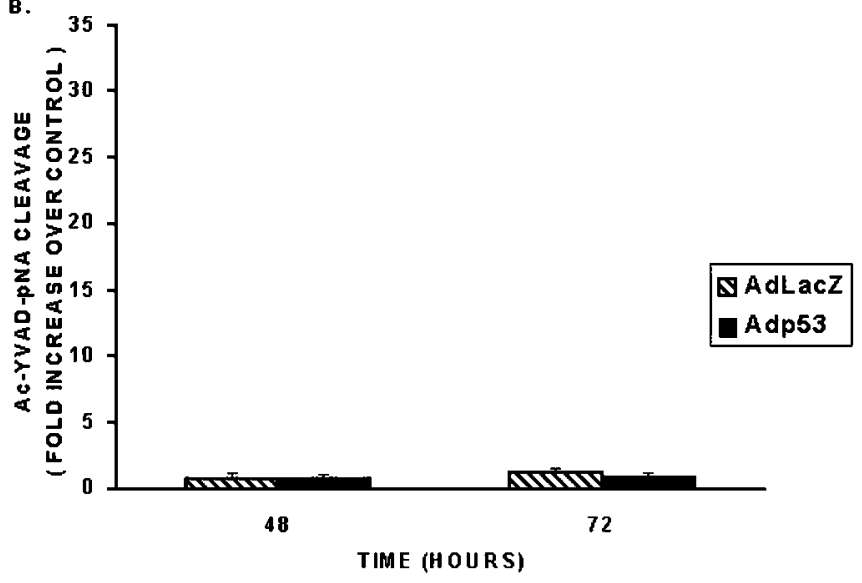

Figure 5. p53 induces caspase-3-like activity in cerebellar granule neurons. Neurons were infected at $50 \mathrm{MOI}$ with AdLacZ or Adp53 at the time of plating. After 48 and $72 \mathrm{hr}$, protein was extracted, and caspase activity was measured. $A$, Caspase- 3 like activity determined by measurement of AcDEVD-pNA cleavage. $B$, Caspase-1 like activity as determined by AcYVAD-pNA cleavage. Activity is shown as fold increase over control (uninfected replicate dishes), and bars represent the mean with error bars indicating SD; $n=3$. Each $n$ represents a cell culture derived from a separate experiment.

$\beta$-galactosidase reporter gene (AdLacZ). The AdLacZ vector was used to determine the efficiency of transduction as well as to assess the effect of viral infection on neuronal viability as described previously (Slack et al., 1996). At a virus titer of 50 MOI, $>90 \%$ of neurons infected with AdLacZ were found to express high levels of $\beta$-galactosidase as determined by X-gal staining (Fig. 1). After $72 \mathrm{hr}$ in culture, uninfected neurons and neurons infected with the control virus AdLacZ displayed healthy cell bodies and an extensive neuritic network (Fig. $2 A, D$ ). In contrast, neurons infected with Adp53 exhibited obvious signs of cellular degradation, including phase-bright, pyknotic cell bodies as well as blebbing and dissolution of neuritic processes (Fig. 2G). This cell death was accompanied by a significant increase in the fraction of cells exhibiting chromatin condensation (Fig. 2B,E,H) and positive TUNEL labeling (Fig. $2 C, F, I$ ), indicative of an apoptotic mode of cell death.

To confirm that this cell death was associated with increased expression of p53, neurons infected at 50 MOI with either Adp53 or AdLacZ were immunostained with an antibody specific for

\section{Con. AdLacZ Adp53 Con. AdLacZ Adp53}

\section{CPP32}

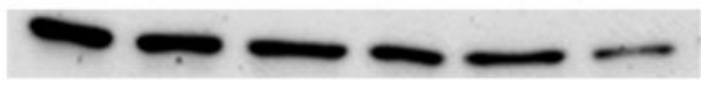

\section{Actin}

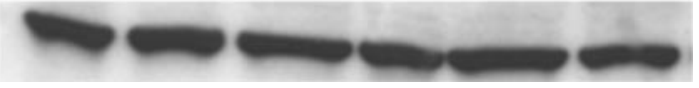

Figure 6. p53 induces the cleavage of caspase-3 protein in cerebellar granule neurons. Cells were either uninfected or infected with AdLacZ or Adp53 at $50 \mathrm{MOI}$, and protein was harvested at 48 and $72 \mathrm{hr}$ for Western blot analysis. After SDS-PAGE, protein was transferred to nitrocellulose filters and probed with an antibody specific for mouse caspase-3, and loading was standardized with actin. Note the disappearance of the $32 \mathrm{kd}$ band $72 \mathrm{hr}$ after infection with Adp53.

human p53 to distinguish from endogenous p53. As expected, neurons infected with AdLacZ were not immunoreactive for human p53 (Fig. $3 A, B$ ), whereas $>80 \%$ of the neurons infected with Adp53 exhibited intense immunopositive staining (Fig. $3 C, D)$. To determine more precisely the extent of transgene expression, cell extracts were prepared from CGN cultures 48 and $72 \mathrm{hr}$ after infection with AdLacZ or Adp53, and the level of p53 protein was assessed by Western blot analysis, this time using an antibody that recognizes both rodent and human p53. These experiments demonstrate that infection with Adp53 resulted in a substantial increase in p53 expression within $48 \mathrm{hr}$ of infection (Fig. 4). The lack of detectable p53 in extracts from uninfected cells or cells infected with AdLacZ suggests that the endogenous levels of p53 were comparatively small and that the infection process itself did not significantly alter p53 expression in these cells. Taken together, these results indicate that expression of p53 can directly induce apoptotic cell death in cultured cerebellar granule neurons.

\section{Caspase-3 is activated in P53-mediated cell death}

Caspase-3 (CPP32) has been implicated as a key player in certain models of neuronal apoptosis (Kuida et al., 1996; Keane et al., 1997). To determine whether caspase- 3 might be involved in p53-mediated neuronal cell death, we measured caspase-3 activity in cell extracts from CGNs after infection with Adp53 by monitoring the cleavage of its colorimetric substrate DEVD-pNA. Neurons infected with Adp53 exhibited a time-dependent increase in caspase-3-like activity relative to control neurons (Fig. 5). Infection with Adp53 resulted in a threefold increase in caspase-3-like activity at $48 \mathrm{hr}$ and a 14-fold increase at $72 \mathrm{hr}$ as compared with the control virus AdLacZ. Furthermore, Western blot analysis revealed a significant decrease in the level of caspase-3 proenzyme in extracts from neurons infected with Adp53 consistent with its cleavage into active caspase-3 (Fig. 6). These results suggest that caspase-3 is activated during p53mediated cell death in cerebellar granule neurons.

To determine whether other effector caspases may also be involved in this pathway, we examined caspase- 1 and -2 activity after infection with Adp53. Caspase-1 activity was measured by cleavage of the colorimetric substrate YVAD-pNA. However, no significant increase in caspase-1 activity could be detected at either 48 or $72 \mathrm{hr}$ after infection with Adp53 (Fig. 5B). Furthermore, Western blot analysis revealed no change in the level of caspase- 2 proenzyme levels at either 48 or $72 \mathrm{hr}$ (data not shown). 
A.

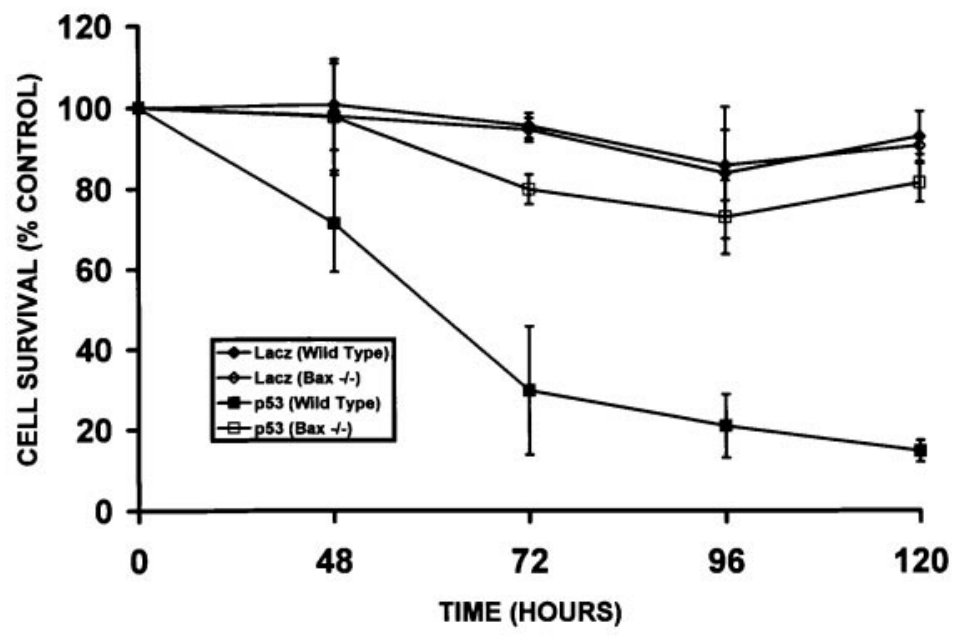

B.

AdLacZ

Figure 7. Bax deficiency renders cerebellar granule neurons resistant to p53-induced cell death. $A$, Cells were either uninfected or infected with AdLacZ or Adp53 at $50 \mathrm{MOI}$, and an MTT survival assay was conducted at 48, 72, 96, and $120 \mathrm{hr}$. Control, uninfected cells were considered $100 \%$, and results are reported as the percentage of control. Points are the average of cultures derived from three separate brains with matching wild-type littermates $(n=3)$, with error bars showing SD. $B$, Phase-contrast photomicrographs of Bax $+/+$ and $-/-$ neurons $72 \mathrm{hr}$ after infection at $50 \mathrm{MOI}$ with either AdLacZ or Adp53. Scale bar, $60 \mu \mathrm{m}$.

These results suggest that caspase- 1 and -2 are not involved in this cell death pathway.

\section{Bax-deficient neurons are resistant to p53-induced cell death}

To determine whether Bax was required in this p53-mediated cell death pathway, cell survival was examined in CGNs derived from Bax wild-type and Bax-deficient mice after infection with either Adp53 or AdLacZ. In Bax +/+ neurons, a significant decrease in cell survival could be detected as early as $48 \mathrm{hr}$ after infection with Adp53 (Fig. 7A). Neuronal cell death continued to increase gradually with time, and by $96 \mathrm{hr}$ there was an approximate $80 \%$ loss in neuronal survival. In contrast, Bax $-/-$ neurons infected with Adp53 exhibited only a marginal decrease in cell survival relative to AdLacZ controls that remained constant for at least $120 \mathrm{hr}$ after infection. Consistent with this increased resistance, Bax-deficient neurons infected with Adp53 appeared remarkably healthy when examined by light microscopy (Fig. 7B).

To determine whether this enhanced survival of Bax-deficient neurons was associated with a decrease in apoptotic cell death, Bax $+/+$ and Bax $-/-$ neurons were infected with Adp53 or AdLacZ, and the frequency of TUNEL-positive cells was determined after $72 \mathrm{hr}$. In Bax $+/+$ neurons, infection with Adp53 resulted in a dramatic increase in the frequency of TUNELpositive cells $(\sim 70 \%)$ in comparison with neurons infected with
Bax $+/+$
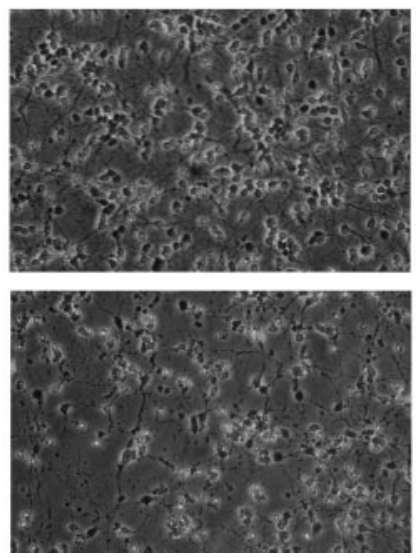

the control virus AdLacZ (Fig. 8). In contrast, Bax-/- neurons infected with Adp53 exhibited only a small increase in TUNELpositive cells $(\sim 10 \%)$ relative to control. The fact that p53mediated cell death is dramatically reduced in the absence of Bax suggests that Bax must play a prominent role in this cell death pathway.

Bax has been shown to be transcriptionally regulated by $\mathrm{p} 53$ (Miyashita et al., 1994; Miyashita and Reed, 1995), and Bax induction has been observed in certain p53-mdiated cell death paradigms (Selvakumaran et al., 1994; Zhan et al., 1994; Brady et al., 1996). Therefore, we examined Bax protein expression in wild-type cerebellar granule neurons after infection with Adp53. Interestingly, p53 overexpression did not cause a significant increase in Bax protein levels (data not shown). Therefore, although Bax appears to play a critical role in p53-mediated cell death, this did not appear to involve induction of Bax expression.

\section{Bax is required for p53-induced caspase-3 activation}

We next examined caspase- 3 activity in $\mathrm{Bax}+/+$ and $\mathrm{Bax}-/-$ neurons after infection with Adp53 to determine whether Bax was required for p53-mediated caspase-3 activation. In Bax $+/+$ neurons, infection with Adp53 resulted in an approximately 13-fold increase in caspase-3 like activity as compared with the control virus AdLacZ (Fig. 9). This increase in caspase-3 like activity, 
A.

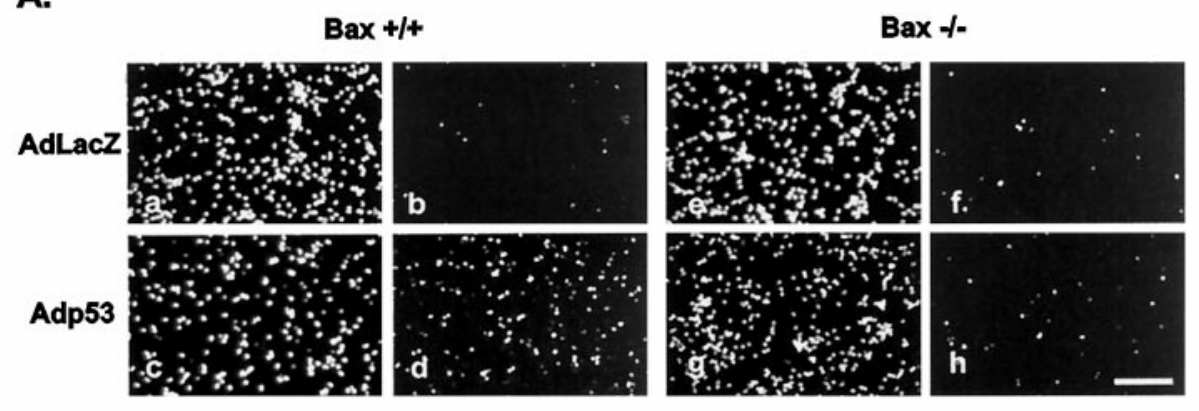

B.

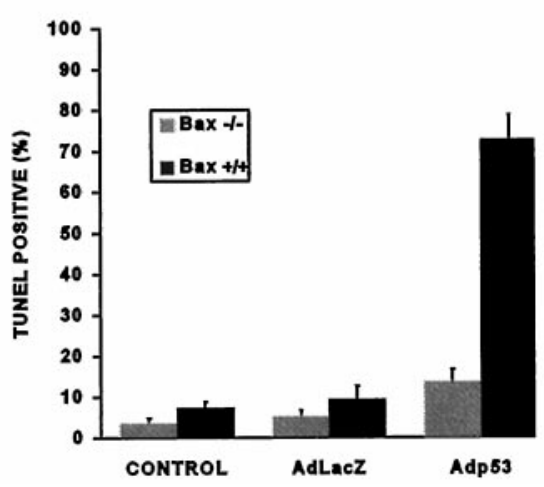

Figure 8. Bax-deficient neurons are resistant to p53-mediated apoptosis. Cerebellar granule neurons were infected at $50 \mathrm{MOI}$ with AdLacZ or Adp53 at the time of plating. $A$, After $72 \mathrm{hr}$ in culture, Bax $+/+(a-d)$ or Bax $-/-(e-h)$ neurons were fixed and stained with TUNEL $(b, d, f, h)$ and counterstained with Hoechst $(a, c, e, g)$. Scale bar, $100 \mu \mathrm{m}$. B, Quantitation of TUNEL-positive cells. Data represent the mean and SD from three independent experiments.

however, was absent in Bax-deficient neurons (Fig. 9), indicating that $\mathrm{Bax}$ is required for $\mathrm{p} 53$-induced caspase- 3 activation.

\section{Caspase-3-deficient neurons exhibit increased resistance to P53-induced cell death}

Because caspase-3 appears to be the predominant caspase involved in p53-induced cell death, we next asked whether caspase-3 was required in this p53-mediated cell death pathway. Survival was examined in CGNs derived from CPP32 $+/+$ or CPP32 - / - mice after infection with Adp53. The genotype of these mice was determined by PCR, and the absence of caspase-3 protein was confirmed by Western blot analysis (Fig. 10). Similar to Bax-deficient neurons, neurons deficient in caspase-3 were found to be significantly more resistant to p53-induced cell death than their wild-type counterparts (Fig. 11). However, survival in CPP32 - / neurons infected with Adp53 did eventually decline relative to control cultures infected with AdLacZ (Fig. 11A). This indicates that the absence of caspase- 3 delays cell death within the first $96 \mathrm{hr}$, but death will ensue independent of caspase-3. Consistent with the observed decrease in survival, after $72 \mathrm{hr}$ CPP32-/- neurons infected with Adp53 exhibited some signs of cell death when examined by light microscopy; however, they appeared significantly more intact than similarly treated CPP32+/+ neurons (Fig. 11B). These results suggest that although caspase-3 appears to be involved in p53-induced cell death, there may be additional death pathways through which p53 and Bax can mediate their effects.

It has been suggested that caspase- 3 is responsible for the activation of endonucleases involved in the internucleosomal DNA fragmentation process that occurs during apoptosis (Enari et al., 1998; Sakahira et al., 1998). Therefore, TUNEL labeling was examined in caspase-3-deficient neurons to determine whether apoptotic DNA fragmentation was being blocked in these cells. Consistent with this hypothesis, the fraction of TUNEL-positive cells was significantly decreased in CPP32-/neurons after infection with Adp53 as compared with control neurons infected with AdLacZ (Fig. 12). Furthermore, most TUNEL-positive neurons in the CPP32-/- cultures did not exhibit the characteristic pyknotic nucleus and highly condensed chromatin structure typically observed in wild-type neurons (data not shown).

\section{DISCUSSION}

Recent evidence indicates that p53 is a pivotal molecule regulating the death of many cell types, including postmitotic neurons (White, 1996; Hughes et al., 1997). We therefore examined the molecular mechanisms by which p53 induces apoptosis in neuronal cells. The results of these experiments support a number of conclusions. First, we demonstrate that p53-induced apoptosis in cerebellar granule neurons results in a strong activation of caspase-3. Second, caspase-3 activity and the subsequent cell death induced by p53 is dependent on the presence of Bax. Cells deficient in Bax exhibit normal morphology and little change in survival relative to LacZ controls, despite the presence of p53.

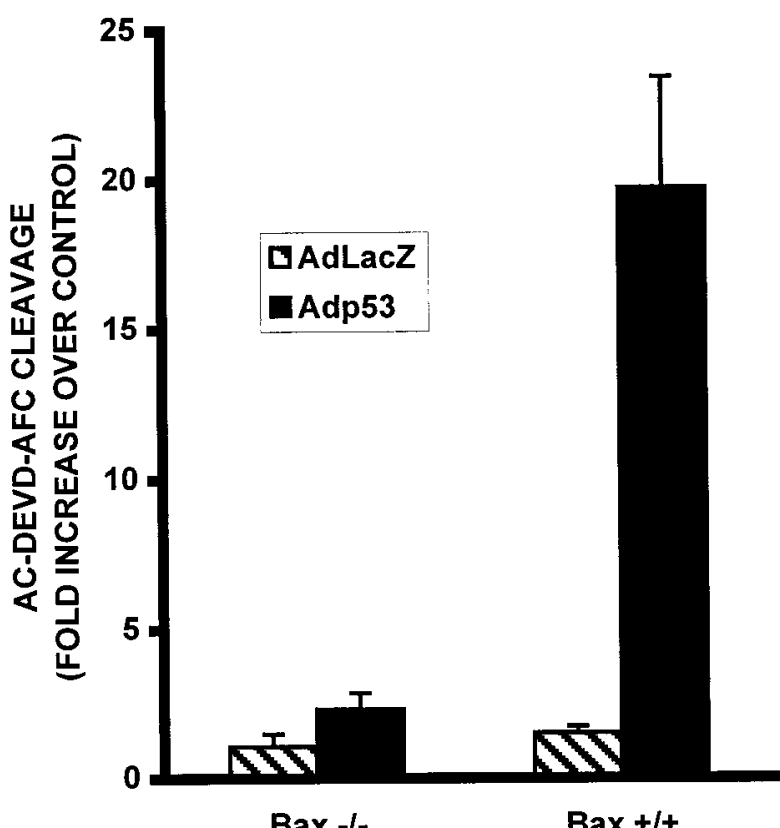

Figure 9. p53-induced caspase-3-like activity is dependent on Bax. Neurons were infected at 50 MOI with AdLacZ or Adp53 at the time of plating. After $72 \mathrm{hr}$ in culture, protein was extracted, and AcDEVDAFC cleavage activity was measured in Bax-deficient and wild-type cells. Bars represent the average of three separate experiments, and error bars show SD. 
CPP32

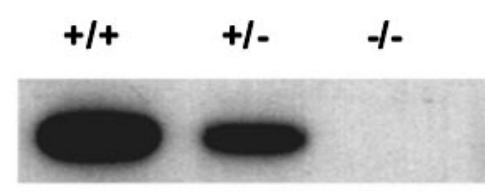

ACTIN

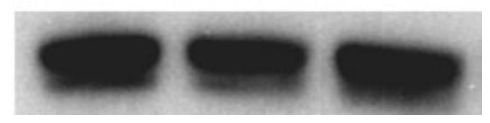

Figure 10. Absence of caspase-3 expression in CPP32 mutant mice. Protein was extracted from brains derived from wild-type $(+/+)$, heterozygous $(-/+)$, and CPP32 null $(-/-)$ mice, and Western blot analysis was performed. Filters were probed with mouse monoclonal antibodies directed against caspase- 3 and actin.

Third, in the absence of caspase-3, p53-induced apoptosis is remarkably delayed in cerebellar granule neurons, indicating the involvement of caspase-3. In conclusion, p53-induced cell death in postmitotic neurons involves a Bax-dependent caspase- 3 activation that is a key determinant in neuronal cell death.

We and others have shown that adenovirus-mediated p53 gene delivery to postmitotic neurons results in apoptosis (Slack et al., 1996; Xiang et al., 1996; Jordan et al., 1997). Because of the potential toxicity of adenoviral vectors (Slack and Miller, 1996; Slack et al., 1996; Easton et al., 1998) in neuronal cells, viral titers must be rigorously controlled, particularly in the context of neuronal apoptosis. Accordingly, we have used a minimal viral titer of $50 \mathrm{MOI}$ that results in $90-100 \%$ infection of cerebellar granule cells with minimal cytotoxic effects. Neurons infected with AdLacZ (50 MOI) exhibit only a slight $10 \%$ decrease in survival after $96 \mathrm{hr}$ relative to those infected with Adp53, which exhibited a $65-80 \%$ loss of viability. Similarly, AdLacZ infection resulted in only a slight increase in caspase-3 activation, whereas infection with Adp53 produced a 20- to 25-fold enhancement in DEVD cleavage. Thus, we conclude that the cell death and caspase activation induced in cerebellar granule neurons was primarily caused by the delivery of the p53 gene.

To determine whether Bax is essential to induce caspase-3 activation and the death of cerebellar granule neurons, experiments were conducted on Bax-deficient cells. Our results indicated that in the absence of Bax, no significant increase in caspase-3 activation was evident. Furthermore, neurons infected with p53 in the absence of Bax remained viable even after $96 \mathrm{hr}$. Cell bodies and processes remained intact, with no signs of degeneration, indicating that Bax-deficient cells were protected from p53-induced apoptosis. Previous studies examining p53-

A.

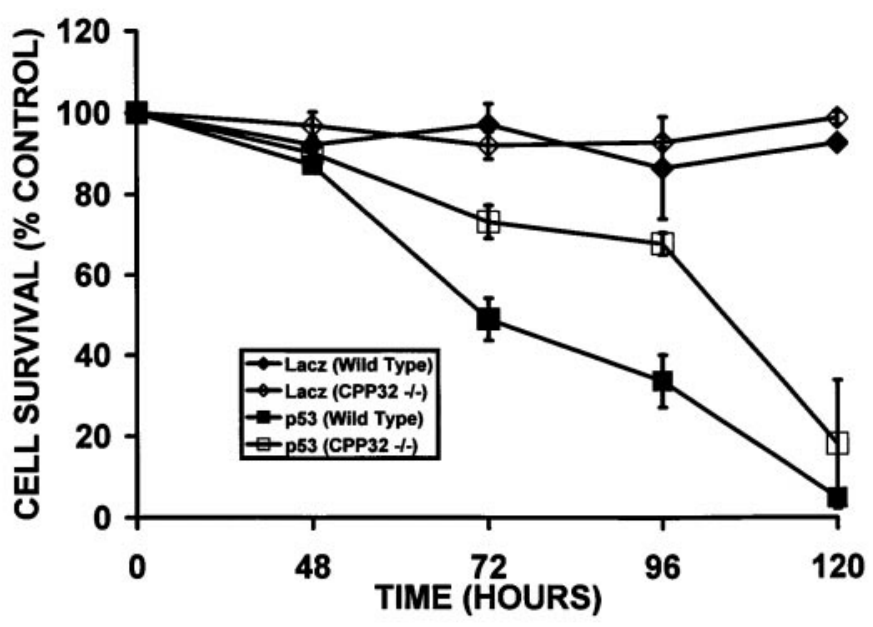

B.
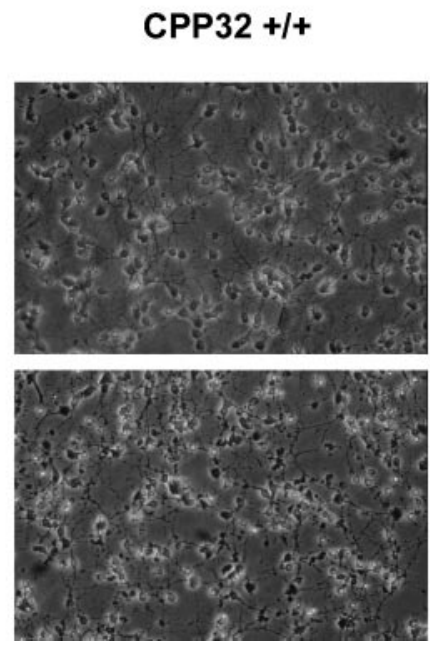

Figure 11. Caspase-3-deficient neurons exhibit a delay in p53-induced cell death. $A$, Cells were either uninfected or infected with AdLacZ or Adp53 at 50 MOI, and an MTT survival assay was conducted at 48, 72, 96, and $120 \mathrm{hr}$. Control, uninfected cells were considered $100 \%$, and results are reported as the percentage of control. Points are the average of cultures derived from three separate brains with matching wild-type littermates $(n=3)$, with error bars showing SD. B, Phase-contrast photomicrographs of CPP32 $+/+$ and $-/-$ neurons $72 \mathrm{hr}$ after infection at 50 MOI with either AdLacZ or Adp53. Scale bar, $60 \mu \mathrm{m}$.

\section{AdLacZ}

Adp53

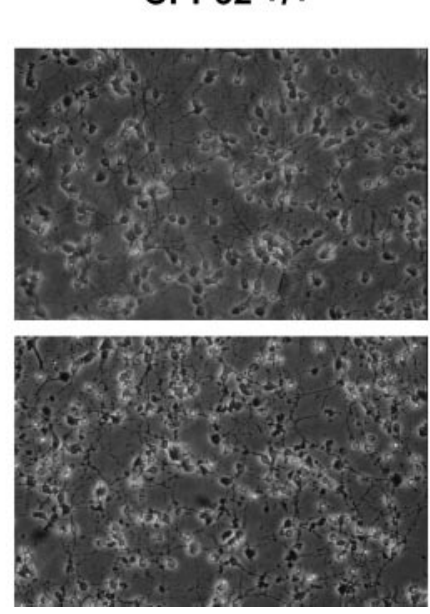

CPP32 \%-
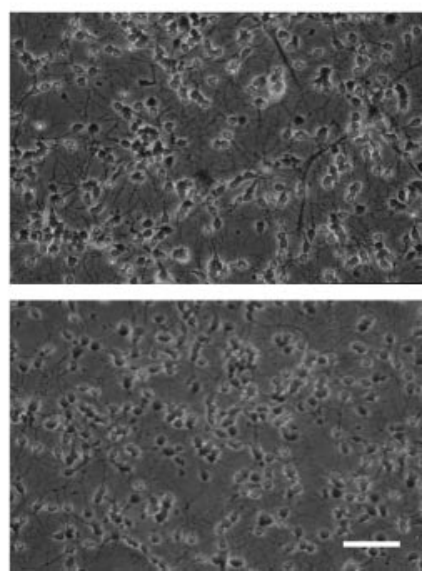
A.

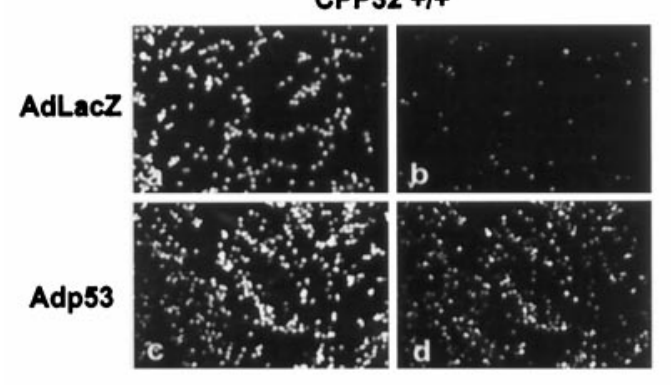

CPP32 +1+

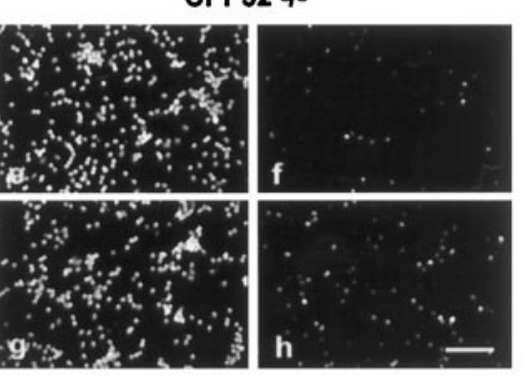

B.

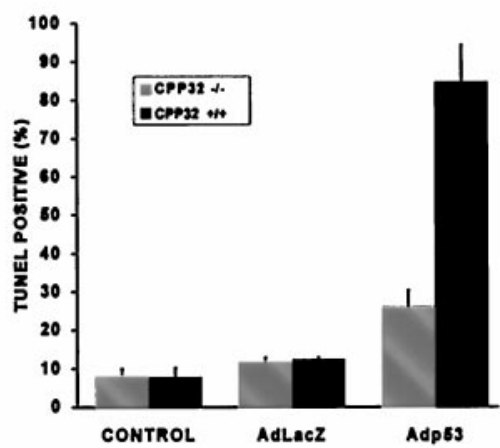

Figure 12. Caspase-3-deficient neurons expressing p53 exhibit decreased TUNEL staining. Cerebellar granule neurons were infected at 50 MOI with AdLacZ or Adp53 at the time of plating. $A$, After $72 \mathrm{hr}$ in culture, CPP32 $+/+(a-d)$ or CPP32-/- $(e-h)$ neurons were fixed and stained with TUNEL $(b, d, f, h)$ and counterstained with Hoechst $(a, c, e, g)$. Scale bar, $100 \mu \mathrm{m}$. B, Quantitation of TUNEL-positive cells. Data represent the mean and SD from three independent experiments.

induced cell death in Bax-deficient cortical neurons demonstrated significant protection at viral titers up to $250 \mathrm{MOI}$; however, cells infected at higher titers (500 MOI) exhibited significant cell death despite the absence of Bax (Xiang et al., 1998). Thus, the involvement of Bax in p53-induced apoptosis in cortical neurons remains unclear. It is possible that the function of Bax in the cell death process could vary depending on the cell type being examined. One advantage of cerebellar granule neurons is that relatively low viral titers (50 MOI) are sufficient to transduce $90-100 \%$ of the cells. Under these conditions, Bax-deficient neurons are clearly protected against p53-induced apoptosis.

It has been proposed that p53-mediates cell death through transcriptional induction of the Bax gene. Consistent with this proposal, the Bax gene has been reported to contain a p53responsive element within its promoter region (Miyashita et al., 1994; Miyashita and Reed, 1995), and Bax induction has been observed during p53-mediated cell death in certain cell systems (Selvakumaran et al., 1994; Zhan et al., 1994; Brady et al., 1996). Although this study demonstrates that adenovirus-mediated p53 transduction can induce Bax-dependent cell death in cerebellar granule neurons, this does not appear to require upregulation of Bax expression (results not shown). Likewise, it has been reported that Bax protein levels are not elevated during camptothecin- or radiation-induced cell death of cortical and hippocampal neurons, respectively, although cell death was demonstrated to be Bax-dependent (Johnson et al., 1998; Xiang et al., 1998).

The mechanism by which Bax becomes activated in the absence of increased protein levels is not clear. Recent reports, however, have indicated that after exposure to certain apoptotic stimuli Bax is translocated from the cytoplasm to the mitochondrial membrane and that this process is essential for cell death to occur (Wolter et al., 1997; Goping et al., 1998; Zhang et al., 1998). One hypothesis is that Bax forms pores in the mitochondrial membrane, resulting in depolarization and the consequent release of cytochrome c. Cytoplasmic cytochrome c has been reported to facilitate the interaction between APAF-1 and caspase-9, resulting in the activation of the caspase cascade (Li et al., 1997; Zou et al., 1997). Bax activity could also be affected by alterations in the activity of Bax binding partners such as Bcl-XL (Oltvai et al., 1993; Merry and Korsmeyer, 1997). It is believed that Bax promotes cell death when in its homodimeric form but is inactive when heterodimerized with anti-apoptotic family members (Oltvai and Korsmeyer, 1994; for review, see Adams and Cory, 1998). Thus, Bax may be activated indirectly by the downregulation of its anti-apoptotic antagonists.

The results of the present study indicate that p53-mediated activation of caspase- 3 is dependent on Bax. Previous studies have shown that Bax is required for caspase activation after potassium withdrawal-induced cell death of cerebellar granule neurons (Miller et al., 1997). Furthermore, it has been demonstrated that Bax overexpression itself can induce caspase activation in neuronal cells (Vekrellis et al., 1997; Martinou et al., 1998). Thus, one possible mechanism by which Bax may function in the p53-mediated cell death pathway is through the activation of caspases. Our finding that caspase-3-like activity was essentially blocked in Bax-deficient neurons is consistent with this interpretation. It should be noted, however, that the Bax mutation results in significantly greater protection against cell death than the caspase- 3 null mutation, clearly indicating that Bax has functions beyond the activation of caspase-3-like activity.

The question as to why the Bax mutation is protective against p53-induced apoptosis whereas caspase-3 deficiency results in a delay of apoptosis may be explained by the involvement of multiple caspases. Previous studies have shown that Bax is a key regulator of caspase activation in neuronal cell types (Miller et al., 1997; Vekrellis et al., 1997). Thus, it is possible that other caspases may be activated in response to p53-mediated Bax activation, thereby facilitating cell death in the absence of caspase-3. Alternatively, Bax may initiate a caspase-independent death program in caspase-3-deficient cells. Previous studies using pancaspase inhibitors have suggested that Bax can evoke a caspaseindependent program to execute cell death (Miller et al., 1997). The fact that caspase-3-deficient neurons eventually die but do not exhibit the typical pyknotic morphology supports the possibility that a caspase-independent death program may be involved.

Neuronal cell death induced by adenovirus-mediated p53 delivery was significantly delayed in caspase-3-deficient neurons. However, caspase-3 does not appear to play an essential role in this death pathway because caspase-3-deficient neurons expressing p53 did eventually die. Unlike CPP32 +/+ neurons, CPP32deficient neurons did not exhibit typical chromatin condensation, suggesting that caspase- 3 is involved in the breakdown of the nucleus and DNA fragmentation in neuronal cells. Indeed, one 
prominent function of caspase-3 appears to be in the activation of caspase-activated deoxyribonuclease (CAD). CAD has been implicated as one of the endonucleases responsible for cleavage of DNA into internucleosomal fragments characteristic of apoptosis (Enari et al., 1998; Sakahira et al., 1998).

In summary, p53-induced cell death has been shown to occur in response to a wide range of cellular perturbations, including DNA damage, cell cycle deregulation, and more recently, ischemic insult in neurons (for review, see Ko and Prives, 1996; Hughes et al., 1997). Results from our studies as well as those of other laboratories have demonstrated that p53 expression alone is capable of inducing apoptosis in postmitotic neurons (Slack et al., 1996; Xiang et al., 1996; Jordan et al., 1997). The mechanisms by which p53 can induce cell death are complex and vary depending on the cell type examined (for review, see Ding and Fisher, 1998). To determine the precise mechanism by which p53 functions in neuronal cells, we questioned the involvement of Bax, one of the putative regulatory targets for p53 (Miyashita et al., 1994), and caspase-3, a key regulator of neuronal cell death during development (Kuida et al., 1996). The results of our experiments demonstrate that p53 mediates a Bax-dependent caspase- 3 activation in neurons, and that in the absence of caspase- 3 a significant delay in neuronal cell death occurs. We therefore show that Bax and caspase- 3 are key determinants in the p53 apoptotic signaling cascade in neurons.

\section{REFERENCES}

Adams JM, Cory S (1998) The Bcl-2 protein family: arbiters of cell survival. Science 281:1322-1325.

Aloyz RS, Bamji SX, Pozniak CD, Toma JG, Atwal J, Kaplan DR, Miller FD (1998) P53 is essential for developmental neuron death as regulated by the TrkA and p75 neurotrophin receptors. J Cell Biol 143:1691-1703.

Bacchetti S, Graham FL (1993) Inhibition of cell proliferation by an adenovirus vector expressing the human wild-type p53 protein. Int $\mathbf{J}$ Oncol 3:781-788.

Banasiak KJ, Haddad GG (1998) Hypoxia-induced apoptosis: effect of hypoxic severity and role of p53 in neuronal cell death. Brain Res 29:295-304.

Brady HJ, Solomons GS, Bobel dijk RC, Berns AJ (1996) T-cells from bax-alpha transgenic mice show accelerated apoptosis in response to stimuli but do not show restored DNA damage induced cell death in the absence of p53. EMBO J 15:1221-1230.

Cheng Y, Deshmukh M, D'Costa A, Demaro JA, Gidday JM, Shah A, Sun Y, Jacquin MF, Johnson EM, Holtzman DM (1998) Caspase inhibitor affords neuroprotection with delayed administration in a rat model of neonatal hypoxic-ischemic brain injury. J Clin Invest 101:1992-1999.

Chopp M, Li Y, Zhang ZG, Freytag SO (1992) P53 expression in brain after middle cerebral artery occlusion in the rat. Biochem Biophys Res Commun 182:1201-1207.

Clarke AR, Maandag ER, Van Roon M, Van der Lugt NMT, Van der Valk M, Hooper MI, Berns A, Te Riele H (1992) Requirement for a functional Rb-1 gene in murine development. Nature 359:328-330.

Crumrine RC, Thomas AL, Morgan PF (1994) Attenuation of p53 expression protects against focal ischemic damage in transgenic mice. J Cereb Blood Flow Metab 14:887-891.

Deckwerth TL, Elliott JL, Knudson CM, Johnson EM, Snider WD, Korsmeyer SJ (1996) Bax is required for neuronal death after trophic factor deprivation and during development. Neuron 17:401-411.

Ding HF, Fisher DE (1998) Mechanisms of p53-mediated apoptosis. Crit Rev Oncol 9:83-98.

Easton RM, Johnson EM, Creedon DJ (1998) Analysis of events leading to neuronal death after infection with E1-deficient adenoviral vectors. Mol Cell Neurosci 11:334-347.

Enari M, Sakahira H, Yokoyama H, Okawa K, Iwamatsu A, Nagata S (1998) A caspase-activated DNase that degrades DNA during apoptosis, and its inhibitor ICAD. Nature 391:43-50.

Endres M, Namura S, Shimizu-Sasamata M, Waeber C, Zhang L, Gomez-
Isla T, Hyman BT, Moskowitz MA (1998) Attenuation of delayed neuronal death after mild focal ischemia in mice by inhibition of the caspase family. J Cereb Blood Flow Metab 18:238-247.

Gillardon F, Bottiger B, Schmitz B, Zimmermann M, Hossmann KA (1997) Activation of CPP-32 protease in hippocampal neurons following ischemia and epilepsy. Brain Res Mol Brain Res 50:16-22.

Goping IS, Gross A, Lavoie JN, Nguyen M, Jemmerson R, Roth K, Korsmeyer SJ, Shore GC (1998) Regulated targeting of Bax to mitochondria. J Cell Biol 143:207-215.

Gottron FJ, Ying HS, Choi DW (1997) Caspase inhibition selectively reduces the apoptotic component of oxygen-glucose deprivationinduced cortical neuronal cell death. Mol Cell Neurosci 9:159-169.

Hara H, Friedlander RM, Gagliardini V, Ayata C, Fink K, Huang Z, Shimizu-Sasamata M, Yuan J, Moskowitz MA (1997) Inhibition of interleukin 1beta converting enzyme family proteases reduces ischemic and excitotoxic neuronal damage. Proc Natl Acad Sci USA 94:2007-2012.

Henderson CE (1996) Programmed cell death in the developing nervous system. Neuron 17:579-585.

Hughes PE, Alexi T, Schreiber SS (1997) A role for the tumour suppressor gene p53 in regulating neuronal apoptosis. NeuroReport 8:5-12.

Jacks T, Fazeli A, Schmitt EM, Bronson RT, Goodell MA, Weinberg RA (1992) Effects of an Rb mutation in the mouse. Nature 359:295-300.

Johnson, MD, Xiang H, London S, Kinoshita Y, Knudson M, Mayberg M, Korsmeyer SJ, Morrison RS (1998) Evidence for involvement of bax and $\mathrm{p} 53$, but not caspases, in radiation-induced cell death of cultured postnatal hippocampal neurons. J Neurosci Res 54:721-733.

Jordan J, Galindo RS, Prehn JHM, Weichselbaum RR, Beckett M, Ghadge GD, Roos RP, Leiden JM, Miller RJ (1997) p53 expression induces apoptosis in hippocampal pyramidal neuron cultures. J Neurosci 17:1397-1405.

Keane RW, Srinivasan A, Foster LM, Testa MP, Ord T, Nonner D, Wang HG, Reed JC Bredesen DE, Kayalar C (1997) Activation of CPP32 during apoptosis of neurons and astrocytes. J Neurosci Res 48:168-180.

Knudson CM, Tung KSK, Tourtelotte WG, Brown GAJ, Korsmeyer SJ (1995) Bax-deficient mice with lymphoid hyperplasia and male germ cell death. Science 270:96-99.

Ko LJ, Prives C (1996) p53: puzzle and paradigm. Genes Dev 10:1054-1072.

Kuida K, Zheng TS, Na S, Kuan C-Y, Yang D, Karasuyama, Rakic HP, Flavell RA (1996) Decreased apoptosis in the brain and premature lethality in CPP32-deficient mice. Nature 384:368-372.

Kuida K, Haydar T, Kuan C-Y, Gu Y, Taya C, Karasuyama H, Su MS-S, Rakic P, Flavell RA (1998) Reduced apoptosis and cytochrome c-mediated caspase activation in mice lacking caspase 9. Cell 94:325-337.

Lee EHP, Chang CY, Hu N, Wang YCJ, Lai CC, Herrup K, Lee WH, Bradley A (1992) Mice deficient for Rb are nonviable and show defects in neurogenesis and haematopoiesis. Nature 359:288-294.

Levi GF, Aloisi MT, Ciotti A, Gallo V (1984) Autographic localization and depolarization-induced release of acidic amino acids in differentiating cerebellar granule cell cultures. Brain Res. 290:77-86.

Li P, Nijhawan D, Budihardjo I, Srinivasula SM, Ahmad M, Alnemri ES, Wang X (1997) Cytochrome c and dATP- dependent formation of APAF-1/caspase-9 complex initiates an apoptotic protease cascade. Cell 91:479-489.

Li Y, Chopp M, Zhang ZG, Zaloga C, Niewenhuis L, Gautam S (1994) P53-immunoreactive protein and p53 mRNA expression after transient middle cerebral artery occlusion in rats. Stroke 25:849-855.

Li Y, Sharov VG, Jiang N, Zaloga C, Sabbah HN, Chopp M (1995) Ultrastructural and light microscopic evidence of apoptosis after middle cerebral artery occlusion in rat. Am J Pathol 146:1045-1051.

Linnik MD, Zobrist RH, Hatfield MD (1993) Evidence supporting a role for programmed cell death in focal cerebral ischemia in rats. Stroke 24:2002-2009.

Loddick SA, MacKenzie A, Rothwell NJ (1996) An ICE inhibitor, $z$-VAD-DCB attenuates ischemic brain damage in the rat. NeuroReport 7:1465-1468.

MacManus JP, Buchan AM, Hill IE, Rasquinha I, Preston E (1993) Global ischemia can cause DNA fragmentation indicative of apoptosis in rat brain. Neurosci Lett 164:89-92.

Martinou I, Missotten M, Fernandez PA, Sadoul R, Martinou JC (1998) Bax and Bak proteins require caspase activity to trigger apoptosis in sympathetic neurons. NeuroReport 9:15-19.

McGahan L, Hakim AM, Robertson GS (1998) Hippocampal myc and 
p53 expression following transient global ischemia. Mol Brain Res 56:133-145.

Merry DE, Korsmeyer SJ (1997) Bcl-2 gene family in the nervous system. Annu Rev Neurosci 20:245-267.

Miller TM, Johnson Jr EM (1996) Metabolic and genetic analysis of apoptosis in rat cerebellar granule cells. J Neurosci 16:7487-7495.

Miller TM, Moulder KL, Knudson CM, Creedon DJ, Deshmukh M, Korsmeyer SJ, Johnson EM (1997) Bax deletion further orders the cell death pathway in cerebellar granule cells and suggests a caspaseindependent pathway to cell death. J Cell Biol 139:205-217.

Miyashita T, Reed JC (1995) Tumor suppressor p53 is a direct transcriptional activator of the human Bax gene. Cell 80:293-299.

Miyashita TS, Krajewski S, Krajewska M, Wang HG, Lin HK, Liebermann DK, Hoffman B, Reed JC (1994) Tumour suppressor p53 is a regulator of bcl-2 and Bax gene expression in vitro and in vivo. Oncogene 9:1799-1805.

Morrison RS, Wenzel HJ, Kinoshita Y, Robbins CA, Donehower LA, Schwartzkroin PA (1996) Loss of the p53 tumor suppressor gene protects neurons from kainate-induced cell death. J Neurosci 16:1337-1345.

Ni B, Wu X, Su Y, Stephenson D, Smalstig EB, Clemens J, Paul SM (1998) Transient global forebrain ischemia induces a prolonged expression of the caspase- 3 mRNA in rat hippocampal CA1 pyramidal neurons. J Cereb Blood Flow Metab 18:248-256.

Nitatori T, Sato N, Waguri S, Karasawa Y, Araki H, Shibanai K, Kominami E, Uchiyama Y (1995) Delayed neuronal death in the CA1 pyramidal cell layer of the gerbil hippocampus following transient ischemia is apoptosis. J Neurosci 15:1001-1011.

Oltvai ZN, Korsmeyer SJ (1994) Checkpoints of dueling dimers foil death wishes. Cell 79:189-192.

Oltvai ZN, Milliman CL, Korsmeyer SJ (1993) Bcl-2 heterodimerizes in vivo with a conserved homolog, Bax, that accelerates programmed cell death. Cell 74:609-619.

Oppenheim RW (1991) Cell death during development of the nervous system. Annu Rev Neurosci 14:453-501.

Park DS, Morris EJ, Stefanis L, Troy CM, Shelanski ML, Geller HM, Greene LA (1998) Multiple pathways of neuronal death induced by DNA-damaging agents, NGF deprivation, and oxidative stress. J Neurosci 18:830-840.

Portera-Cailliau C, Hedreen JC, Price DL, Koliatsos VE (1995) Evidence for apoptotic cell death in Huntington disease and excitotoxic animal models. J Neurosci 15:3775-3787.

Rink A, Fung KM, Trojanowski JQ, Lee VM, Neugebauer E, McIntosh TK (1995) Evidence of apoptotic cell death after experimental traumatic brain injury in the rat. Am J Pathol 147:1575-1583.

Sakahira H, Enari M, Nagata S (1998) Cleavage of CAD inhibitor in CAD activation and DNA degradation during apoptosis. Nature 391:96-99.

Sakhi S, Sun N, Wing LL, Mehta P, Schreiber SS (1996) Nuclear accumulation of p53 protein following kainic acid-induced seizures. NeuroReport 7:493-496.

Selvakumaran M, Lin HK, Miyashita T, Wang HG, Krajewski S, Reed
JC, Hoffman B, Liebermann D (1994) Immediately early upregulation of bax expression by 533 but not TGF $\beta 1$ : a paradigm for distinct apoptotic pathways. Oncogene 9:1791-1798.

Slack RS, Miller FD (1996) Viral vectors for modulating gene expression in neurons. Curr Opin Neurobiol 6:576-583.

Slack RS, Belliveau DJ, Rosenberg M, Atwal J, Lochmuller H, Aloyz R, Haghighi A, Lach B, Seth P, Cooper E, Miller FD (1996) Adenovirusmediated gene transfer of the tumor suppressor, p53, induces apoptosis in postmitotic neurons. J Cell Biol 135:1085-1096.

Smale G, Nichols NR, Brady DR, Finch CE, Horton WE (1995) Evidence for apoptotic cell death in Alzheimer's disease. Exp Neurol 133:225-230.

Stefanis L, Park DS, Yan CYI, Farinelli SE, Troy CM, Shelanski ML, Green LA (1996) Induction of CPP32-like activity in PC12 cells by withdrawal of trophic support. J Biol Chem 48:30663-30671.

Thompson CB (1995) Apoptosis in the pathogenesis and treatment of disease. Science 267:1456-1462.

Thornberry NA, Lazebnik Y (1998) Caspases: enemies within. Science 281:1312-1316.

Uberti D, Belloni M, Grilli M, Spano P, Memo M (1998) Induction of tumour-suppressor phosphoprotein 53 in the apoptosis of cultured rat cerebellar neurons triggered by excitatory amino acids. Eur J Neurosci 10:246-254.

Vekrellis K, McCarthy MJ, Watson A, Whitfield J, Rubin LL, Ham J (1997) Bax promotes neuronal cell death and is downregulated during the development of the nervous system. Development 124:1239-1249.

White E (1996) Life, death, and the pursuit of apoptosis. Genes Dev 10:1-15.

Wolter KG, Hsu Y-T, Smith CL, Nechushtan A, Xi XG, Youle RJ (1997) Movement of Bax from the cytosol to mitochondria during apoptosis. J Cell Biol 139:1281-1292.

Woo M, Hakem R, Soengas MS, Duncan GS, Shahinian A, Kagi D, Hakem A, McCurrach M, Khoo W, Kaufman SA, Senaldi G, Howard T, Lowe SW, Mak TW (1998) Essential contribution of caspase-3/ CPP32 to apoptosis and its associated nuclear changes. Genes Dev 12:806-819.

Xiang H, Hochman DW, Saya H, Fujiwara T, Schwartzkroin PA, Morrison RS (1996) Evidence for p53-mediated modulation of neuronal viability. J Neurosci 16:6753-6765.

Xiang H, Kinoshita Y, Knudson CM, Korsmeyer SJ, Schwartzkroin PA, Morrison RS (1998) Bax involvement in p53-mediated neuronal cell death. J Neurosci 18:1363-1373.

Zhan Q, Fan S, Bae I, Guillof C, Liebermann DA, O'Conner PM, Fornace AJ (1994) Induction of bax by genotoxic stress in human cells correlates with normal p53 status and apoptosis. Oncogene 9:3743-3751.

Zhang H, Heim J, Meyhack B (1998) Redistribution of Bax from cytosol to membranes is induced by apoptotic stimuli and is an early step in the apoptotic pathway. Biochem Biophys Res Commun 251:454-459.

Zou H, Henzel WJ, Liu X, Lutschg A, Wang X (1997) Apaf-1, a human protein homologous to $C$. elegans CED-4 participates in cytochrome c-dependent activation of caspase-3. Cell 90:405-413. 